\title{
EVALUATION OF AGRONOMIC PERFORMANCE OF DROUGHT - TOLERANT QTL INTROGRESSION HYBRIDS OF MILLET (Pennisetum glaucum L R. BR.) IN THE GUINEA SAVANNAH ZONE OF GHANA
}

\author{
DEMUYAKOR B..$^{*}$, GALYUON I. ${ }^{3}$, KYEREH S. ${ }^{2}$, AHMED M. ${ }^{2}$ \\ 1Department of Biotechnology, Faculty of Agriculture, University for Development Studies, Box TL 1882, Tamale, Ghana. \\ 2Department of Agronomy, Faculty of Agriculture, University for Development Studies, Box TL 1882, Tamale, Ghana. \\ ${ }^{3}$ Department of Molecular Biology and Biotechnology, University of Cape Coast, Cape Coast, Ghana. \\ ${ }^{*}$ Corresponding Author: Email- bawainghana2@yahoo.co.jp
}

Received: June 26, 2013; Accepted: July 16, 2013

\begin{abstract}
The development of crops adapted to the semi-arid and arid regions would enhance food security in Africa. As part of research towards ensuring food security, field trials were carried out to evaluate the performance of sixteen hybrids of drought tolerant Quantitative trait loci (QTL) introgression lines of pearl millet in a Guinea-Savannah zone of Ghana, where the crop is one of the cereals popularly cultivated by farmers as a staple. The hybrids were obtained from ICRISAT in India and the validation trial was laid out in a randomized complete block design with (4) replicates. All the sixteen lines (843A x H77/833-2, ICML03048 × H77/833-2, ICML03050 × H77/833-2, ICML03051 × H77/833 -2, ICML03052 × H77/833-2, ICML03056 × H77/833-2, ICML03057 × H77/833-2, 841B × H77/833-2, 863B × H77/833-2, 843A × ICMR01029, 843A $\times$ ICMR01031, 843A × ICMR 01040, 843A × ICMR 01046, 843A × ICMR 01042, 843A × ICMR 01044 and 843A $\times$ PRLT2/89-33) were able to withstand the environmental conditions during the trial period. Three entries $(843 \mathrm{~A} \times \mathrm{PRLT} 2 / 89-33,843 \mathrm{~A} \times$ ICMR 01046 and $843 \mathrm{~A} \times$ ICMR 01029) took fewer days to boot. Two hybrids (843A $\times$ H77/833-2 and 843A $\times$ PRLT 2/89-33) had the highest values of 100-seed weight. The hybrid 863B $\times$ H77/833-2 was outstanding in terms of plant height, fresh and dry stover weights, ear head length and diameter; 100-seed weight, head yield and grain yield. It is, therefore, concluded that marker-assisted selection could be used to breed for high yielding millet cultivars in drought prone savannah agro-ecological zones of northern Ghana to enhance yields and improve food security.
\end{abstract}

Keywords- Food security, QTL introgression, pearl millet, yield

Citation: Demuyakor B., et al (2013) Evaluation of Agronomic Performance of Drought - Tolerant QTL Introgression Hybrids of Millet (Pennisetum glaucum L R. Br.) in the Guinea Savannah Zone of Ghana. International Journal of Agriculture Sciences, ISSN: 0975-3710 \& EISSN: 0975-9107, Volume 5, Issue 1, pp.-354-358.

Copyright: Copyright@2013 Demuyakor B., et al. This is an open-access article distributed under the terms of the Creative Commons Attribution License, which permits unrestricted use, distribution and reproduction in any medium, provided the original author and source are credited.

\section{Introduction}

Millet is a collective term referring to a number of small seeded annual grasses that are cultivated as grain crops, primarily, on marginal lands in dry areas in temperate and subtropical regions. The most important species are pearl millet (Pennisetum spp.), finger millet (Eleusinian caracara), proso millet (Panicum miliaceum), and foxtail millet (Setaria italica). Pearl millets (Pennisetum glaucum, $P$. typhoides, and $P$. americanum) are the most widely grown and accounts for $50 \%$ of global millet production [1]. Pennisetum glaucum (L) R. Brown, is commonly known as pearl, bulrush, cattail, or spiked millet in English; bajra in Hindi; kambu in Tamil, and dukhn in Arabic, and kyi in Dagaare. Among the cereals, it is the crop of the driest region. It is drought-resistant and yields well on infertile sandy soils which could be unsuitable for other important cereal groups. It thrives well on light-textured and well-drained soils, and does not tolerate water-logging and flooding [2-3]. Millet is grown in areas with a rainfall of $125-900 \mathrm{~mm}[4]$. Hence, the crop is normally reserved for areas where maize and sorghum fail [5], because of low rainfall or adverse soil factors [6]. Millet grain is nutritious and form a major staple food for over 500 million people in some parts of Africa and India [2].
Pearl millet provides cheap source of protein, minerals, and vitamins to the poorest of the poor who need such ingredients the most. The dehusked pearl millet has a protein content of $12.5 \%$ and calcium (344 mg/100 g) compared to wheat grain (11.8\%) and (41 $\mathrm{mg} / 100 \mathrm{~g}$ ), respectively. After dehusking, the grain may be cooked like rice or ground into flour to make porridge, or cake. Also, the grain is used to produce malt, or feed livestock and poultry, while the green plants provide a useful fodder. The straw may be fed to livestock, or used for bedding, thatching, fencing, and fuel [7]. In Ghana, two varieties- early and late maturing millets- are grown in the Northern or Guinea/Sudan savanna zones. The early millets, which are usually cultivated to prevent prolonged hunger from the lean season, are susceptible to drought spells. This crop usually withers and dies off when there is low rainfall which widens the hunger gap between the rainy and dry seasons. For this reason, hybrids of drought-tolerant QTL introgression lines of millets were developed through international collaborative research works. However, the performance of these varieties needs to be assessed in the growing regions before introducing them to farmers. The objective of this field trial was to evaluate and identify which of the new drought-tolerant QTL introgression hybrids of millet would best with- 
stand drought, give best growth parameters and grain yields in the Guinea Savannah zone of Ghana, where the crop is popularly grown for food.

\section{Materials and Methods \\ Experimental Site and Agro-Climatic Details}

The study was conducted at the experimental field of the Faculty of Agriculture, University for Development Studies, Nyankpala Campus, Northern Region of Ghana. The field is located on latitude $9^{\circ} 25^{\prime \prime} \mathrm{N}$, longitude $0^{\circ} 58 \mathrm{~W} \mathrm{~W}$ and at an altitude of $183 \mathrm{~m}$ above sea level [8]. The area falls within the Guinea Savannah zone. The soil is classified as a Haplic Lixisol and locally referred to as the 'Kpalsawgu' series, which consist of yellow-brown clay and silt, developed from local colluviums [9]. The rainfall pattern is unimodal, which starts from May to October with an average annual value of $1043 \mathrm{~mm}$. The average annual temperature and humidity are $28.3^{\circ}$ $\mathrm{C}$ and $58 \%$, respectively.

\section{Plant Culture and Treatments (Experimental Crops)}

Sixteen (16) hybrids of drought-tolerant QTL introgression lines of pearl millet [Table-1] were obtained from the International Crop Research Institute of Semi-Arid Tropics (ICRISAT) in India.

Table 1- Sixteen drought-tolerant QTL introgression hybrids of pearl millet

\begin{tabular}{|c|c|}
\hline Entry Number & Entry Name \\
\hline 1 & $843 \mathrm{~A} \times \mathrm{H} 77 / 833-2$ \\
\hline 2 & ICML 03048×H77/833-2 \\
\hline 3 & ICML 03050×H77/833-2 \\
\hline 4 & ICML 03051×H77/833-2 \\
\hline 5 & ICML 03052×H77//833-2 \\
\hline 6 & ICML 03056×H77/833-2 \\
\hline 7 & ICML 03057×H77/833-2 \\
\hline 8 & $841 \mathrm{~B} \times \mathrm{H77} / 833-2$ \\
\hline 9 & $863 \mathrm{~B} \times \mathrm{H} 77 / 833-2$ \\
\hline 10 & $843 \mathrm{~A} \times$ ICMR 01029 \\
\hline 11 & $843 \mathrm{~A} \times$ ICMR 01031 \\
\hline 12 & $843 \mathrm{~A} \times$ ICMR 01040 \\
\hline 13 & $843 A \times$ ICMR 01046 \\
\hline 14 & $843 \mathrm{~A} \times$ ICMR 02042 \\
\hline 15 & $843 \mathrm{~A} \times$ ICMR 02044 \\
\hline 16 & 843A×PRLT 2/89-33 \\
\hline
\end{tabular}

QTL= Quantitative trait loci.

\section{Land Preparation and Plot Layout}

The field was ploughed, harrowed twice and ridged with a farm tractor. The experiment was laid out in a randomized complete block design (RCBD) with four replications. In each replication, there were 16 plots with each plot measuring $2 \mathrm{~m} \times 1.2 \mathrm{~m}\left(2.4 \mathrm{~m}^{2}\right)$ and $1 \mathrm{~m}$ between adjacent plots and blocks.

\section{Planting and Other Management Practices}

The sixteen drought-tolerant QTL introgression hybrids were randomly assigned to the plots in each block. About 6-8 seeds of each hybrid were sown per hill on $16^{\text {th }}$ August, 2008 and later thinned (two weeks after emergence) to three seedlings per hill at a spacing of $75 \mathrm{~cm}$ between rows $\times 15 \mathrm{~cm}$ within rows. The total plant population was 54 plants plot $^{-1}$. Four weeks after planting (4WAP) NPK, 15 $-15-15$ fertilizer was applied at the rate of $42 \mathrm{~g} \mathrm{plot}^{-1}$ and 2 weeks later (6WAP) urea was applied as top dressing at the rate of $30 \mathrm{~g}$ plot $^{-1}$ to meet the crops' total nitrogen requirement. Weeding was done manually using a hoe at 5 WAP.

\section{Rainfall Distribution}

Daily rainfalls were recorded in millimeters in order to ascertain the rainfall distribution during the growing period of the crop.

\section{Measurement of growth Characteristics}

Three weeks after planting (3WAP), 5 plants were randomly selected from each plot and tagged for the measurement of growth characteristics at 3, 6 and 9 WAP.

\section{Plant Height (cm)}

Plant height was measured from the base to tip at 3, 6 and 9 WAP. The mean height from the 5 randomly selected plants was taken as the score for each plot.

\section{Fresh and Dry Stover Weights per Plant (g)}

Five plants were randomly selected from each plot at harvest and separated into leaf and stem materials and the fresh weight taken immediately using a balance (Sartorius, TE 612). The mean of the 5 selected plants was computed and used as the fresh stover weight for each plot. The dry stover weight was determined by drying the plant parts to constant weight in an oven set at $80^{\circ} \mathrm{C}$ and the mean dry weight computed for each plot.

\section{Days to $75 \%$ flowering}

The plants were monitored daily and the number of days taken in each plot for $75 \%$ of the millet plants to flower recorded.

\section{Measurement of Yield Traits}

The millet plants were harvested at physiological maturity (14 weeks after planting) at the hard dough stage and the pertinent yield data recorded.

\section{Ear Head Length and Diameter $(\mathrm{cm})$}

The ear head lengths of the 5 randomly selected millet plants were measured separately and the mean computed for each plot. Head diameter was determined using a measuring tape wrapped around the head to find the circumference $(\mathrm{cm})$, which was then divided by $\pi(3.14)$ to get the diameter of each head. The average diameter was computed for each plot.

\section{Hundred-Seed Weight (g)}

Seeds were obtained from the five heads randomly selected from each plot. One hundred (100) seeds were then selected randomly from each head and the weight determined. The average weight was determined and used as the hundred seed weight for the plot.

\section{Head Yield (g)}

All millet heads in a plot were carefully harvested and weighed. The average head yield for each plot was determined by dividing the total yield $(\mathrm{g})$ by the number of heads for each plot.

\section{Grain Yield per Plot (kg)}

All millet heads in each plot were carefully harvested, threshed using a threshing machine and the chaff separated from the grain. The grains collected for each plot were then weighed and recorded as the grain yield for the plot.

\section{Statistical Analysis}

Data obtained was subjected to analysis of variance (ANOVA) using GENSTAT Discovery statistical software (Third Edition). Where significant differences were found, means were separated using the least significant difference (LSD) at $5 \%$ level of significance. 


\section{Result and Discussion}

\section{Plant Height}

Plant heights at 3,6 and 9 WAP varied significantly $(p<0.05)$ among the hybrids [Table-2]. The average plant heights at 3, 6 and 9 WAP were $3.8,44.2$ and $85.6 \mathrm{~cm}$, respectively. Some hybrids (843A $\times$ H77/833-2, ICML 03051 ×H77/833-2, ICML 03052×H77/833 -2, ICML 03057×H77/833-2, 841B × H77/833-2, 863B × H77/833-2, $843 \mathrm{~A} \times$ ICMR 01031, 843A $\times$ ICMR 01046 and 843A $\times$ ICMR 02044) were taller than the average height while others (ICML 03048×H77/833-2, ICML 03050×H77/833-2, ICML 03056×H77/8332, 843A × ICMR 01029, 843A × ICMR 01040, 843A × ICMR 02042 and $843 \mathrm{~A} \times \mathrm{PRLT} 2 / 89-33)$ were shorter than the average height of $85.6 \mathrm{~cm}$ at $9 \mathrm{WAP}$. The hybrids $843 \mathrm{~A} \times \mathrm{H} 77 / 833-2$, ICML $03051 \times \mathrm{H}$ 77/833-2, ICML 03052×H 77/833-2, 863B x H 77/833-2, 843A × ICMR 01046, 843A x ICMR 02044 were significantly $(p<0.05)$ taller than the others at 9 WAP. The differences among the plant heights could be attributed to variations in genotype.

Table 2- Plant heights $(\mathrm{cm})$ of drought - tolerant QTL introgression millet hybrids at 3, 6 and 9 WAP

\begin{tabular}{|c|c|c|c|c|}
\hline Entry Number & Entry name & PH(3WAP) & PH(6WAP) & PH (9WAP) \\
\hline 1 & $843 \mathrm{~A} \times \mathrm{H} 77 / 833-2$ & $3.7^{a b}$ & $65.2^{\mathrm{a}}$ & $90.2^{\mathrm{ab}}$ \\
\hline 2 & ICML 03048×H 77/833-2 & $3.2^{b}$ & $28.1^{\mathrm{b}}$ & $80.0^{\mathrm{ab}}$ \\
\hline 3 & ICML 03050×H 77/833-2 & $3.4^{\mathrm{ab}}$ & $39.1^{b}$ & $82.4^{\mathrm{ab}}$ \\
\hline 4 & ICML 03051×H 77/833-2 & 4.1 ac & $39.3^{b}$ & $97.3^{\mathrm{ab}}$ \\
\hline 5 & ICML 03052×H 77/833-2 & $3.4^{\mathrm{ab}}$ & $47.5^{\mathrm{a}}$ & $93.5^{\mathrm{ab}}$ \\
\hline 6 & ICML 03056×H 77/833-2 & $3.6^{\mathrm{ab}}$ & $30.7^{b}$ & $84.0 \mathrm{ab}$ \\
\hline 7 & ICML 03057×H 77/833-2 & $3.7 \mathrm{ab}$ & $33.7^{b}$ & $87.6 \mathrm{ab}$ \\
\hline 8 & $841 \mathrm{~B} \times \mathrm{H} 77 / 833-2$ & $3.8^{\mathrm{ab}}$ & $41.0^{\mathrm{b}}$ & $85.9 \mathrm{ab}$ \\
\hline 9 & $863 \mathrm{~B} \times \mathrm{H} 77 / 833-2$ & $4.1^{\mathrm{ac}}$ & $36.9^{b}$ & $105.8^{a}$ \\
\hline 10 & $843 \mathrm{~A} \times$ ICMR 01029 & $3.9^{a b}$ & $39.1^{b}$ & $71.9^{b}$ \\
\hline 11 & $843 \mathrm{~A} \times$ ICMR 01031 & $4.4^{\mathrm{ac}}$ & $59.0^{\mathrm{a}}$ & $89.2^{\mathrm{ab}}$ \\
\hline 12 & $843 \mathrm{~A} \times$ ICMR 01040 & $3.6^{\mathrm{ab}}$ & $55.8^{a}$ & $83.8^{a b}$ \\
\hline 13 & $843 A \times I C M R 01046$ & $4.9 c$ & $56.1^{\mathrm{a}}$ & $95.7 \mathrm{ab}$ \\
\hline 14 & $843 \mathrm{~A} \times$ ICMR 02042 & $3.7^{a b}$ & $44.1^{b}$ & $44.1^{c}$ \\
\hline 15 & $843 \mathrm{~A} \times$ ICMR 02044 & $4.2^{\mathrm{ac}}$ & $62.6^{a}$ & $96.5^{\mathrm{ab}}$ \\
\hline 16 & 843A×PRLT 2/89-33 & $3.8^{\mathrm{ab}}$ & $28.5^{b}$ & $81.0^{a b}$ \\
\hline SED & & 0.4248 & 11.08 & 13.26 \\
\hline P-value & & 0.037 & 0.012 & 0.024 \\
\hline
\end{tabular}

Means within a column with different superscripts are significantly $(P<0.05)$ different. $P H=$ Plant height; $W A P=$ Weeks after planting; $S E D=$ Standard error of differences of means.

\section{Fresh and Dry Stover Weights}

The biomass yields (fresh and dry stover weights) of the hybrids of pearl millets are shown in [Table-3]. The hybrids did not vary significantly $(P>0.05)$ in terms of their fresh stover and dry stover weights. The average fresh and dry weights recorded were $382.8 \mathrm{~g}$ and $283.6 \mathrm{~g}$, respectively. Even though there was no significant ( $p>$ 0.05 ) difference between the hybrids, eight hybrids (lines ICML 03050×H77/833-2, ICML 03051×H77/833-2, ICML 03056×H77/8332, 863B $\times$ H77/833-2, 843A $\times$ ICMR 01029, 843A × ICMR 01046, $843 \mathrm{~A} \times$ ICMR 02044, and 843A×PRLT 2/89-33) had fresh stover weights above the mean score while six of the hybrids (ICML 03050×H77/833-2, ICML 03051×H77/833-2, ICML 03056×H77/833$2,863 \mathrm{~B} \times \mathrm{H} 77 / 833-2,843 \mathrm{~A} \times$ ICMR 02044, and 843A $\times \mathrm{PRLT} 2 / 89-$ 33) had dry stover weight below the mean. The insignificant difference in fresh stover and dry stover weights among the millet lines is an indication that these traits were not influenced by the QTL introgressed.
Table 3- Fresh and dry Stover weights of drought-tolerant QTL introgression hybrids of pearl millet

\begin{tabular}{|c|c|c|c|}
\hline \multicolumn{2}{|c|}{ Entry Number Hybrid } & \multicolumn{2}{|c|}{ Fresh Stover Weight Dry Stover Weight } \\
\hline 1 & $843 \mathrm{~A} \times \mathrm{H} 77 / 833-2$ & 368.5 & 280 \\
\hline 2 & ICML 03048×H77/833-2 & 370 & 261.8 \\
\hline 3 & ICML 03050×H77/833-2 & 394.5 & 296.5 \\
\hline 4 & ICML 03051×H77/833-2 & 387.2 & 288.5 \\
\hline 5 & ICML 03052×H77/833-2 & 369.5 & 272.5 \\
\hline 6 & ICML 03056×H77/833-2 & 385.2 & 287 \\
\hline 7 & ICML 03057×H77/833-2 & 369 & 275.2 \\
\hline 8 & $841 \mathrm{~B} \times \mathrm{H} 77 / 833-2$ & 382.8 & 276.8 \\
\hline 9 & $863 \mathrm{~B} \times \mathrm{H} 77 / 833-2$ & 426.5 & 304.5 \\
\hline 10 & $843 A \times I C M R 01029$ & 383.2 & 270.5 \\
\hline 11 & $843 A \times$ ICMR 01031 & 358.5 & 268.2 \\
\hline 12 & $843 \mathrm{~A} \times$ ICMR 01040 & 375.5 & 283.8 \\
\hline 13 & $843 A \times I C M R 01046$ & 390.8 & 283.5 \\
\hline 14 & $843 A \times$ ICMR 02042 & 346 & 252.5 \\
\hline 15 & $843 \mathrm{~A} \times$ ICMR 02044 & 397.2 & 295.5 \\
\hline 16 & 843A×PRLT 2/89-33 & 420 & 341 \\
\hline Mean & & 382.8 & 283.6 \\
\hline SED & & 23.16 & 21.51 \\
\hline $\mathrm{P}$-value & & 0.11 & 0.069 \\
\hline
\end{tabular}

SED = Standard error of difference of means.

\section{Days to $75 \%$ Flowering}

Days to $75 \%$ booting/flowering among the sixteen drought-tolerant QTL introgression hybrids of millet was similar $(p>0.05)$ as shown in [Fig-1]. The number of days to $75 \%$ booting ranged between 58 and 66 days. This is an indication that the introgression of droughttolerant QTL did not affect days to $75 \%$ flowering among millet lines.

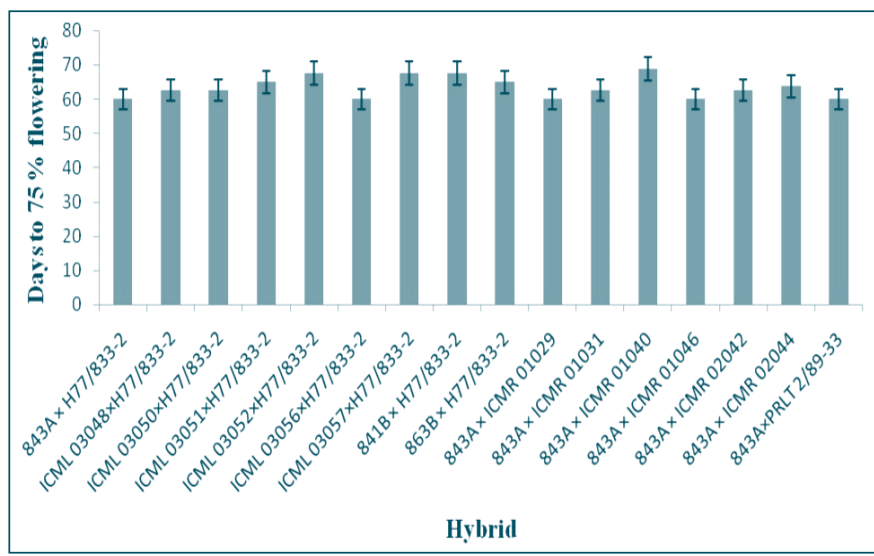

Fig. 1- Number of days to $75 \%$ booting of drought-tolerant QTL introgression pearl millet hybrids. The error bars represent Standard error.

$Q T L=$ Quantitative trait loci.

\section{Ear Head Length and Diameter}

The length and diameter of ear head of the sixteen hybrids of pearl millet are shown in [Table-4]. The average ear head length and ear head diameter recorded were $15.18 \mathrm{~cm}$ and $2.044 \mathrm{~cm}$, respectively. The ear head length and diameters differed significantly $(p<0.05)$ among the hybrids. The hybrids ICML 03048 $\times$ H77/833-2, ICML 03050×H77/833-2, ICML 03051×H77/833-2, ICML 03052×H77/8332, ICML 03056 $\times$ H77/833-2, ICML 03057×H77/833-2, 841B $\times$ H77/833-2, 863B $\times$ H77/833-2843A $\times$ ICMR 01046, and $843 A \times P R L T 2 / 89-33$ had significantly $(p<0.05)$ greater ear head lengths when compared to the other hybrids, while the longest ear head diameter was observed in 863B $\times \mathrm{H} 77 / 833-2,843 \mathrm{~A} \times$ ICMR $01029,843 A \times$ ICMR 01046, and 843AxPRLT 2/89-33. Most of the 
hybrids had ear head length and ear head diameter within the usual range of values $(15-45 \mathrm{~cm}$ and $2-3 \mathrm{~cm}$, respectively) reported for pearl millet [3], which suggests that ear yield was not influenced by the introgression QTL for drought tolerance.

Table 4- Ear head length $(\mathrm{cm})$ and ear head diameter $(\mathrm{cm})$ of pearl millet hybrids.

\begin{tabular}{|c|c|c|c|}
\hline Entry Number & Hybrid & $\begin{array}{c}\text { Ear head } \\
\text { length }(\mathbf{c m})\end{array}$ & $\begin{array}{c}\text { Ear head } \\
\text { diameter }(\mathrm{cm})\end{array}$ \\
\hline 1 & $843 \mathrm{~A} \times \mathrm{H} 77 / 833-2$ & $13.58^{b}$ & $2.062^{b}$ \\
\hline 2 & ICML 03048×H77/833-2 & $15.60^{a}$ & $1.790^{c}$ \\
\hline 3 & ICML 03050×H77/833-2 & $15.14^{a}$ & $1.710^{c}$ \\
\hline 4 & ICML 03051×H77/833-2 & $16.43^{a}$ & $1.838^{c}$ \\
\hline 5 & ICML 03052×H77/833-2 & $15.92^{\mathrm{a}}$ & $1.762^{c}$ \\
\hline 6 & ICML 03056×H77/833-2 & $15.87^{a}$ & $1.703^{c}$ \\
\hline 7 & ICML 03057×H77/833-2 & $16.09^{a}$ & $1.718^{c}$ \\
\hline 8 & $841 \mathrm{~B} \times \mathrm{H} 77 / 833-2$ & $15.82^{a}$ & $1.757^{c}$ \\
\hline 9 & $863 \mathrm{~B} \times \mathrm{H} 77 / 833-2$ & $16.37 \mathrm{a}$ & $2.473^{a}$ \\
\hline 10 & $843 \mathrm{~A} \times$ ICMR 01029 & $14.71^{b}$ & $2.297^{a}$ \\
\hline 11 & $843 \mathrm{~A} \times$ ICMR 01031 & $14.93^{b}$ & $2.268^{b}$ \\
\hline 12 & $843 \mathrm{~A} \times$ ICMR 01040 & $13.76^{b}$ & $2.065^{b}$ \\
\hline 13 & $843 \mathrm{~A} \times$ ICMR 01046 & $15.44^{a}$ & $2.343^{a}$ \\
\hline 14 & $843 \mathrm{~A} \times$ ICMR 02042 & $13.81^{b}$ & $2.180^{b}$ \\
\hline 15 & $843 \mathrm{~A} \times$ ICMR 02044 & $14.06^{b}$ & $2.150^{b}$ \\
\hline 16 & 843A×PRLT 2/89-33 & $15.37 a$ & $2.595^{\mathrm{a}}$ \\
\hline SED & & 0.739 & 0.0963 \\
\hline P-value & & 0.001 & 0.001 \\
\hline
\end{tabular}

Means within the same column with no superscript in common are significantly different SED= Standard error of differences of means.

\section{Hundred-Seed Weight}

The 100-seed weight (g) of the millet lines are shown in [Fig-2]. The millet hybrids had an average weight of $0.650 \mathrm{~g}$ per 100 seeds. Even though the hybrids did not vary significantly, two entries ( $843 \mathrm{~A}$ $\times$ H77/833-2 and 843AxPRLT 2/89-33) showed outstanding performances with 100 -seed weights of $0.753 \mathrm{~g}$ and $0.815 \mathrm{~g}$, respectively, while the hybrids (ICML 03048 $\times \mathrm{H} 77 / 833-2$ and $841 \mathrm{~B} \times \mathrm{H} 77 / 833-2$ ) had the smallest 100 -seed weights $(0.555 \mathrm{~g}$ and $0.500 \mathrm{~g}$, respectively). However, the 100-seed weight values recorded for all the 16 drought-tolerant QTL line hybrids of millet were within the range of values (0.3 -0.8 g/100 seeds) reported for pearl millet in India [10]. This indicates that QTL introduced did not adversely affect seed weight among the hybrids.

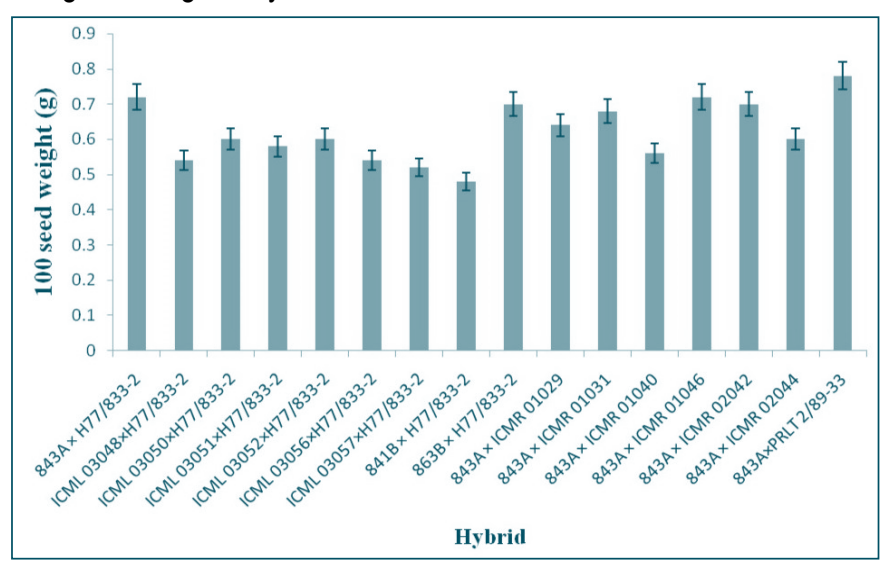

Fig. 2- Average hundred-seed weight (g) of pearl millet hybrids. Error bars represent standard error.

\section{Head Yield Performance}

The head yield was significantly $(p>0.05)$ influenced by the genotype of millet [Fig-3]. The average head yield observed was $76.6 \mathrm{~g}$.
Six entries, namely 843A $\times$ H77/833-2, ICML 03057×H77/833-2, $863 \mathrm{~B} \times \mathrm{H77} / 833-2,843 \mathrm{~A} \times \mathrm{ICMR} 01046,843 \mathrm{~A} \times \mathrm{ICMR} 02044$ and $843 A \times P R L T 2 / 89-33$, performed above average while ten (ICML 03048×H77/833-2, ICML 03050×H77/833-2, ICM 03051×H77/8332, ICML 03052 $\times$ H77/833-2, ICML 03056 $\times$ H77/833-2, 841B $\times$ H77/833-2, 843A x ICMR 01029, 843A x ICMR 01031, 843A $\times$ ICMR 01040, and 843A $\times$ ICMR02042) had values below the mean. The hybrids $863 \mathrm{~B} \times \mathrm{H} 77 / 833-2,843 \mathrm{~A} \times \mathrm{H} 77 / 833-2$ and $843 \mathrm{~A} \times$ ICMR 01046 had significantly $(p<0.05)$ higher head yield than the other hybrids.

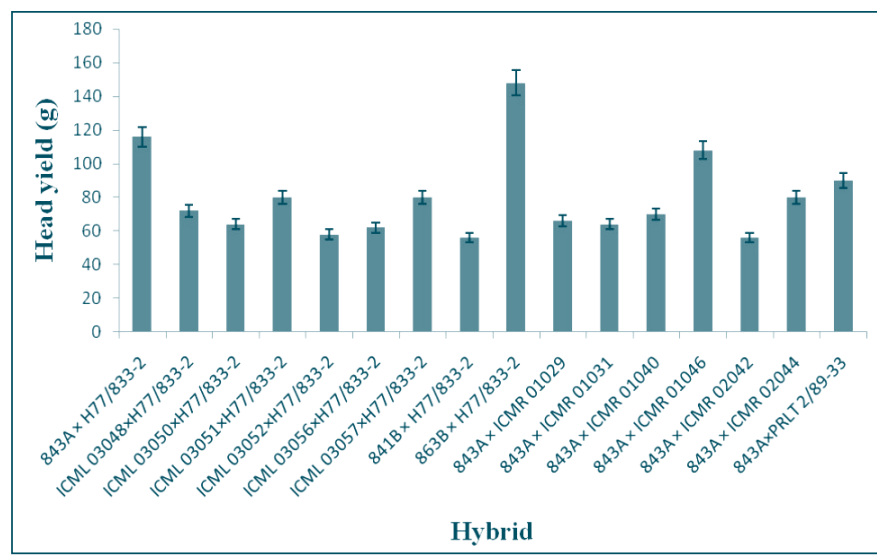

Fig. 3- The head yield $(\mathrm{g})$ of pearl millet hybrids. Error bars represent standard error.

\section{Grain Yield}

Grain production differed significantly $(P<0.05)$ among the drought -tolerant QTL introgression hybrids of millet [Fig-4]. The highest grain yield $(\mathrm{kg} / \mathrm{ha}$ ) was recorded in line 9 (863B $\times \mathrm{H} 77 / 833-2)$, while the lowest yield was observed in line 14 (843A $\times$ ICMR 02042). Indeed line 9 , which produced the greatest grain yield, was the tallest with the highest values for ear head length, ear head diameter, 100-seed weight and head yield. Hence entry number 9 (863B $\times$ H77/833-2) performed best among the 16 hybrids.

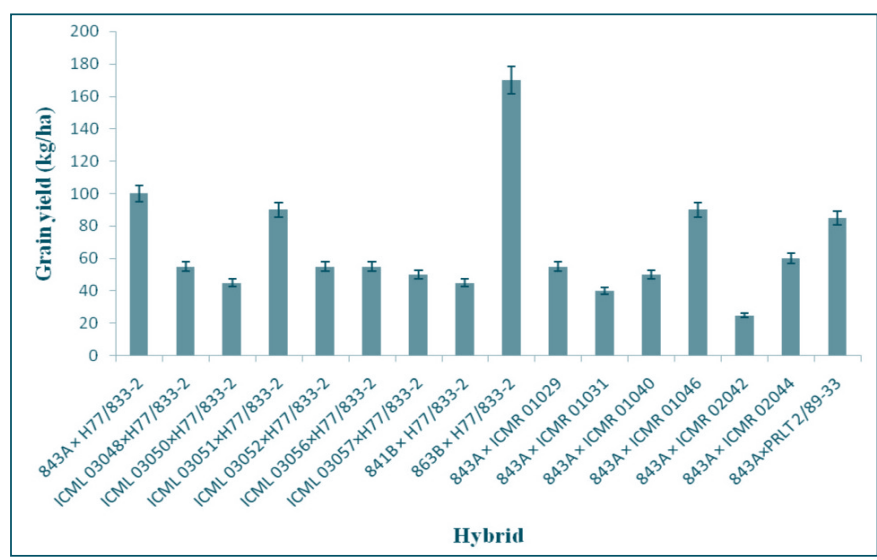

Fig. 4- Mean grain yield of drought-tolerant QTL introgression hybrids of millet. Error bars represent standard error.

$Q T L=$ Quantitative trait loci.

\section{Rainfall Distribution}

The average daily rainfall distributions $(\mathrm{mm})$ during the field trial are shown in [Fig-5]. The rainfall was higher than $100 \mathrm{~mm}$ in the 2nd and 8 th weeks, but very low during the maturity stage $\left(12^{\text {th }}\right.$ to $14^{\text {th }}$ weeks). Although reports indicated that millet can grow in areas with rainfall ranging between 125 and $900 \mathrm{~mm}[4]$, the average rain- 
fall recorded from the 4th week after planting to maturity was far below the average requirement for the plant. The crop needs water for growth and development at this critical period. Therefore, insufficient water supply can reduce crop yield. Despite the inadequate rainfall throughout most of the growing season, all the droughttolerant QTL introgression hybrids of millet were able to grow normal and yield grain.

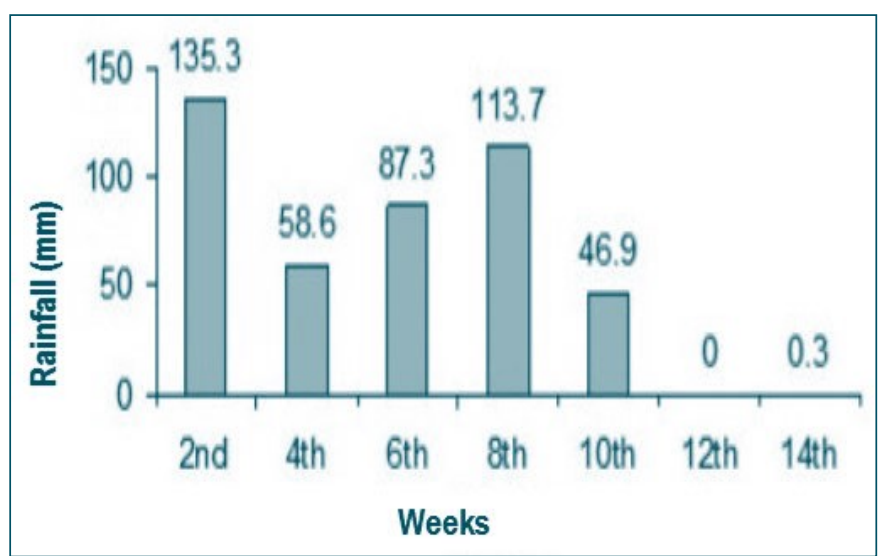

Fig. 5- Rainfall distribution $(\mathrm{mm})$ from sowing to harvesting of drought-tolerant QTL introgression hybrids.

\section{Conclusion and Recommendations}

The study conducted revealed that the hybrid $863 \mathrm{~B} \times \mathrm{H} 77 / 833-2$ had the best performance in terms of plant height, fresh and dry stover weights, ear head length and diameter, 100-seed weight, head yield, and grain yield. Also, accessions 843A $\times$ PRLT 2/89-33, 843A x ICMR 01046, and 843A x ICMR 01029 took fewer days to boot. Generally, the following accessions $843 \mathrm{~A} \times \mathrm{H} 77 / 833-2$, ICML03048 × H77/833-2, ICML03050 × H77/833-2, ICML03051 × H77/833-2, ICML03052 × H77/833-2, ICML03056 × H77/833-2, ICML03057 × H77/833-2, 841B × H77/833-2, 843A × ICMR01031, $843 \mathrm{~A} \times$ ICMR 01040, 843A $\times$ ICMR 01042, and 843A $\times$ ICMR 01044 recorded poor grain filling and quality. Even though all the hybrids survived the inadequate rainfall for most of the growing periods, grain yield produced was very varied. Therefore, there will be the need to conduct more locational trials to evaluate the agronomic performance of the hybrids before recommending the best performing hybrids to farmers. Otherwise, these hybrids with the drought tolerance should be crossed with high yielding but drought susceptible cultivars to breed for high grain yield, which is what the farmers and their households and animals rely on for sustenance.

\section{References}

[1] FAO and ICRISAT (1996) The World Sorghum and Millet economics, facts, trends and outlook, 31-51.

[2] Onwueme T.C. and Sinha T.D. (1991) Field Crop Production of Tropical Africa, Principles and Practice, Technology Centre For Agriculture and Rural Co-operation, 190-199.

[3] Panda S.C. (2005) Agronomy, AGROBIOS, 429-436.

[4] Jain S.V. and Muthur C.M. (1961) Indian Journal of Agronomy, 5(3), 151-156.

[5] Krishnaswamy N. (1962) Bajra: Pennisetum typhoides S \& H, Indian Council of Agriculture Research Cereal Crop Series II.

[6] Burton G.W. (1951) Advance. Agron., 3, 197-241.

[7] Rachie K.O. and Majumuder J.V. (1980) Pearl Millet, Pennsyl- vania State University Park, 1-265.

[8] Nyankpala Agricultural Experimental Station (1992) NAES Annual Report, Nyankpala, Ghana.

[9] FAO/UNESCO (1987) Soil Map of the World Revised Legend, World Soils Resource Report 60. FAO, Rome, 41.

[10]Murty B.R., Upadhyay M.K. and Manchanda P.L. (1967) Indian Journal Genetic Plant Breed, 27. 